Birmingham is indebted to the local authority for an income of $6000 l$. a year, and referred regretfully to the circumstance that the neighbouring local authorities have not contributed very largely to the funds of the university. It must be admitted that the contribution of the city of Birmingham to its university is a handsome tribute to the value attached by the local authority to university instruction, and we join with the Chancellor of the university in hoping that suitable sums of money will be devoted in the near future by local authorities in adjoining areas to the purposes of higher education in the Midlands.

It is, however, to be regretted that $\mathrm{Mr}$. Chamberlain made no reference on this occasion to the important principle-a principle he has conceded already more than once-that higher education, especially in science, is primarily a national charge. As was pointed out in the issue of Nature for March 16 , the present State grant to the University of Birmingham is $4500 l$, an amount. which compares unfavourably with the sum voted by the local city authority. Presiding at the annual meeting of the court of governors of the university on February 6 of this year, Mr. Chamberlain remarked :-

"I may say in passing that the liberality of the local contribution is a ground for the claim which we make for some further State support. It is something that we have found that the Government are becoming alive to our needs and to our deserts, and that they have been able to double the sum previously given for university education. But we may bear in mind at the same time that the present Chancellor of the Exchequer has promised to double it again in his next Budget, and, therefore, I anticipate that from that source we shall receive a very considerable addition. I do not at all accept it as in any way a satisfaction of our demands, because it is my conviction that public opinion will soon insist upon larger sums being devoted to this purpose. When I think that we are spending thirteen millions a year at least on primary education I say the sum now given for the purpose of the highest education, the most profitable of all the investments we can make in that direction, is altogether inadequate."

If it were necessary many similar quotations could be made from Mr. Chamberlain's speeches, for he has always maintained enthusiastically the value of higher education, and recognised, at least in theory, the duty of the State to provide for it adequate financial assistance. It is noteworthy, indeed, that on the part of our leading statesmen there is an almost complete unanimity of opinion as to the paramount importance of higher scientific training for the citizens of a nation which expects to occupy a foremost place in the industrial and commercial pursuits of the world. The Lord Chancellor said in speaking to the undergraduates at Birmingham on Saturday last, that in his judicial capacity he has noticed that "the number of patents invented in Germany and brought over to England is very large indeed; the German Government has contemplated the improvement of its national resources by physical, chemical, and other scientific research, and has established places for physical investigation." Lord Halsbury might also have pointed out the amount of State aid to universities afforded in Germany. The yearly sum, found chiefly by the State, for the upkeep of the University of Berlin is $130,000 l$, and six other universities each receive from the same source annual sums varying from $56,000 l$. to $37,000 l$.

It will be remembered that Sir Norman Lockyer said in his address in IgO3, as president of the British Association, that the State does really concede the principle that higher education should be a national responsibility, by its contribution to our universities and colleges. Since that address was delivered the grant to university collegres has been increased, and it may now be said that the Treasury provides for higher education of the whole country something like the amount that is given by the State to the University of Berlin alone.

But in face of the fact that we have the concession by the Government of the principle we have maintained consistently in these columns, that university education, of the modern kind at least, should be provided by the State; and that our statesmen profess to appreciate the value of higher scientific study so far as our national welfare is concerned, and to trace to their colleges and laboratories for research the success of other nations competing with us in the struggle for national existence; no serious and statesmanlike action is taken by our Government to place our system of higher education upon a broad and generous foundation. Despite years of earnest advocacy by men of science, and repeated object lessons abroad of the advantages which early follow national sacrifices on behalf of education, little progress is made by us in the direction of supplying means to provide trained intelligences to perform the work of the country in the world's markets and manufactories. Yet, unless something in the direction adumbrated is done, knowing the earnest work which is being accomplished elsewhere, this country must, so far as industrial and economic prosperity are concerned, expect soon to take a third or fourth place in the competition of the nations.

A statesman imbued with the modern spirit, aware of present-day tendencies, possessed of the power of persuasion and clear exposition, would have little difficulty - if he really desired the best interests of the nation-in carrying the country with him by insisting that an adequate provision of higher education for those who will manage and control its industrial activities must be made a national charge.

\section{MEETING OF THE BRITISH ASSOCIATION IN SOUTH AFRICA.}

$T H E$ seventy-fifth meeting of the British Association, to be held in South. Africa, under the presidency of Prof. G. H. Darwin; in August, promises to be of an unusually interesting character. Though on two previous occasions the association has met in the "British Dominions beyond the Seas," this is the first on which it will hold its annual meeting in the southern hemisphere and in a part of the British Empire so remote from its headquarters.

As early as the year r 1900 , the possibility of holding such a meeting was discussed by the council of the British Association in consultation with Sir David Gill, who, however, pointed out that the local circumstances were at that time unfavourable. Two years later, however; Sir David Gill informed the association that he was empowered to transmit an invitation vo visit South Africa in 1905 on behalf of the various Governments, municipal, scientific, and commercial bodies. in South Africa: Arrangements have now so far advanced as to enable us to give a preliminary account of the general features of the meeting and its probable character.

The invitation was issued on behalf of the above-mentioned bodies, and substantial financial assistance has been rendered by the South African Governments. The various centres to be visited are also making extensive progress, both financially and by way of private hospitality, to render the arrangements workable and adequate.

A central organising committee, under the chairmanship of Sir David Gill, has been formed to see to the general arrangements and coordination of the

NO. I 855 , roL. 727 
work of the different centres to be visited by the association, and by means of correspondence, circulars, \&c., to keep them in touch with each other and with the executive in England.

The centres, which are seven in number, are as follows :-Cape Town, Durban, Pietermaritzburg, Johannesburg, Bloemfontein, Kimberley, and Bulawayo. Influential local committees have been formed at all these places, the municipal authorities of which have taken a prominent part both in making general arrangements and in affording financial support. Subcommittees for finance, publications, excursions, and hospitality have been formed at the two chief centres (Cape Town and Johannesburg), and are now engaged in the respective parts of the work allotted to them. At the other centres where a stay of only a day or two is contemplated, special committees have also been formed. Details are as yet uncertain, but the following may be mentioned, though some of them are subject to slight revision.

The officers of the association and invited guests to the number of 200 , along with ordinary members, will arrive by the Saxon at Cape Town on August ${ }^{15}$, though a number have already booked their passage by steamers arriving at an earlier date. The presidential address will be delivered on the evening of the same day in the large new Town Hall, which has been placed at the disposal of the British Association by the municipal authorities of Cape Town, not only for this purpose, but also for the accommodation of the various sections should it prove suitable.

The sections will meet for the purpose of reading papers and for discussion on Wednesday, Thursday, and Friday, August 16,17 , and 18 . The afternoons of these days will be partly devoted to excursions to places of interest, such as Table Mountain, Hout Bay, Simons Town, and Royal Observatory. The whole of Saturday, August 19, will be devoted to excursions.

The evenings will probably be devoted to a reception by the Mayor, and two lectures, one by Prof. Poulton on Burchell's work in South Africa, and another by Mr. C. V. Boys on physics.

On Saturday night, August I9, visitors will leave by a special steamer for Durban. In Natal an influential general committee has been formed by the Government, with local committees at Durban, Pietermaritzburg, and Ladysmith. On the evening of August 20 a lecture will be delivered at Durban and another on August 24 at Pietermaritzburg. As the reading of papers, discussions, receptions, \&c., in Cape Colony will fully occupy all the time of the visitors, it is intended to afford as much facility as possible for independent action on the part of visitors in Natal, and special arrangements will be made by the Natal committee for visiting the battlefields and other places of interest.

The sectional work will be again resumed on arrival of the party at Johannesburg on Monday, August 28. There, as at Cape Town, a large and influential local committee has been formed, with subcommittees for finance, hospitality, publication, and excursions. The first-named subcommittee has already met with a ready response, both from the municipal authorities and from private sources, and the other committees are in capable hands. While the natural facilities for excursions to be found near the Cape peninsula are not to be met with here, the interest of the mining operations and gold extracting processes will be an adequate compensation, and a Friday's visit to Pretoria will be of special interest.

The proceedings will be begun at Johannesburg on Monday evening, August 28, and the presidential address there will be delivered on the Wednesday evening. In addition to sectional papers and discussions, there will be two lectures delivered at Johannesburg, one on distribution of power by Prof. Ayrton, another on steel as an igneous rock by Prof. Arnold, and one at Pretoria by Prof. Porter on mining.

Bloemfontein will be visited on Saturday, September 2. There also an influential local committee has been formed, and preparations are being made for the reception of visitors. A lecture will be delivered there on the Saturday night by Mr. A. R. Hinks on an astronomical subject.

At Kimberley, which will be reached on Tuesday, September 5, a large local committee has been formed, with subcommittees for special objects. Two lectures will probably be delivered here, one on a zoological subject by Mr. A. E. Shipley, and one on diamonds by Sir William Crookes. The De Beers Company has naturally taken a prominent part in the preparations, and will probably make this visit one of the most interesting.

Through the kindness of the Chartered Company a limited number of members of the British Association will be enabled to proceed from there to the Zambezi, where the Victoria Falls will be visited, and facilities will be afforded for the visit of a select party of specialists to the ancient ruins of Zimbabwe. A special committee at Bulawayo has been formed to make preparations there for the visit.

Special attention will be directed to certain interesting problems connected with the geological formation at the Victoria Falls, and Mr. G. W. Lamplugh, who will go out in advance to study this subject, will probably be able to give the results of his observations in an afternoon address to Section C.

Though this meeting of the association will be characterised by the number and variety of the places visited, a special feature will be the study of local scientific problems and discussions of a general nature such as fossil reptiles, Antarctica, \&c. With this in view the South African Association for the Advancement of Science, with the support of the various Governments, is preparing a handbook, which will be a general review of the various branches of scientific activity in South Africa, the articles being contributed by actual workers in these subjects in the country. The book is now in an advanced stage of preparation, and a copy will be presented to each member of the association before leaving England.

\section{SIR BERNHARD SAMUELSON, P.C., BART., F.R.S.}

GIR BERNHARD SAMUELSON, F.R.S., who $S$ died on May to in his eighty-fifth year, will be remembered as one of the pioneers of the Cleveland iron trade, and a strenuous advocate of technical education. He exerted a great and formative influence upon an industry which owes its progress largely to the application of scientific methods, and the extension of facilities for technical education is largely due to his efforts.

Sir Bernhard Samuelson was born on November 22 , 1820 , and began in 1853 the business which speedily made the Cleveland district the greatest iron-producing centre in the world. Blast furnaces were erected near Middlesbrough, and in $1872-1880$ collieries and ironstone mines were added. Not content with making pig-iron, the manufacture of finished iron was undertaken on an extensive scale, and no less than $25,000 l$. were spent in preliminary experiments in steel-making. The Britannia Ironworks at Middlesbrough, covering an area of twenty acres, have grown out of this enterprise.

$\mathrm{He}$ was the author of several reports on technical subjects to the House of Commons, including one on technical education of artisans at home and abroad.

NO. I 855 , voL. 72$]$ 